Jason Bragg ${ }^{1}$, Alberto Alvarez-Castillo², Monica Trejo-Duran ${ }^{3}$ and Victor Castano ${ }^{1}$

\title{
PREPARATION AND PROPERTIES OF (EPOXY RESIN)/ (NYLON 6,6 OLIGOMER) BLENDS
}

\author{
${ }^{1}$ Centro de Fisica Aplicada y Tecnologia Avanzada, Universidad Nacional Autonoma de M exico \\ Apartado Postal 1-1010 Queretaro, 76001 Queretaro, M exico; castano@ fata.unam.mx \\ 2 Instituto Tecnologico de Zacatepec, Lab. de M ateriales "Dr. Fernando Alba Andrade", \\ Calzada Tecnologico No. 2 7, A.P. 45, Zacatepec, Morelos, C.P. 62780 M exico \\ ${ }^{3}$ Universidad de Guanajuato, FIMEE, Salamanca, Guanajuato, M exico
}

Received: February 24, 2009

(c) Bragg J., Alvarez-Castillo A., Trejo-Duran M., Castano V. 2009

\begin{abstract}
A series of polymer alloys based on different compositions of Nylon 6,6 oligomers (NYL66Ors) and epoxy resin have been prepared. The oligomer was extracted from the waste residues of the industrial production of nylon 6,6 and was dissolved in the epoxy resin. The mixture was crosslinked at $333 \mathrm{~K}$ using dodecenylsuccinic anhydre (DDSA) as a curing agent. The tensile strength and flexural modulus were found to increase with the addition of NYLO66O up to a maximum value of $2 \mathrm{wt} \%$ oligomer content. Both, the tensile and impact strength show a maximum increase due to the addition of $35 \mathrm{wt} \%$ NYLO66O. The compressive strength testing revealed a considerable increase, up to $87 \%$, over that of the neat epoxy with the addition of $1 \mathrm{wt} \%$ NYLO66O. An interesting relationship between the mechanical properties and the developed morphology of the blends has been found.
\end{abstract}

Key words: epoxy resin, oligomer, mechanical properties, Nylon 6,6.

\section{Introduction}

The blending of existent polymers to create new materials with enhanced properties has become a successful alternative to the expensive synthesis of completely new polymers. The possible combinations of polymers seem endless, and for the past 30 years, research has resulted in a large number of commercial applications. However, there is a lack of information concerning the modification of polymers with oligomers, and only a handful of research worldwide groups have investigated this novel approach [1-6]. This is an important route because oligomers have unique properties, different from those of polymers. From the ecological standpoint, the polymer industry produces vast quantities of oligomers as waste products of the industrial fabrication of most plastics, resins, and engineering polymers.

Accordingly, it has been reported that the modification of unsaturated polyester resin with a polyethylene terephthalate oligomer produces a semi-IPN (Interpenetrating Polymer Network) which increases elongation to break with increasing oligomer content [7]. Since the spatial microstructure plays a key role in these semi-IPN blends, it is important to perform characterisation which as in other polymer blends have already been reported $[5,6]$, that may lead to a better understanding of the complex synthesis-microstructureproperties relationship. Epoxy resin has been extensively modified with polymers such as rubbers, polyetherimides, poly(butylene terephthalate) and polysulfones which act as impact modifiers to reduce the brittle behaviour of the epoxy matrix. However, to our knowledge only one other investigation has been performed regarding the modification of an epoxy resin with an oligomer. In this present work an oligoimide was prepared through a Michael Addition reaction and was blended with an epoxy resin [1-4]. The oligomer was extracted from the industrial polymerisation residues of nylon 6,6. The change in mechanical properties and phase separation due to varying proportions of epoxy resin and nylon 6,6 oligomer in the blend was studied in terms of failure mechanisms, FTIR, and morphological features.

\section{Experimental}

\subsection{Materials}

NYLO66O was extracted from the residues of industrial (DuPont, Mexico City plant) nylon 6,6 polymerisation. The exact separation procedure and characterisation of NYLO66O will be reported in an 
oncoming paper. A commercially-available epoxy resin was purchased from Compania Mexicana de Resinas. The resin is based on diglycidyl ether of bisphenol A (DGEBA) and Dodecenylsuccinic anhydride (DDSA) was used as the crosslinking agent.

\subsection{Preparation of Blends}

Different quantities $(1,2,5,10$, and $35 \mathrm{wt} \%)$ of extracted NYLO66O were added as a liquid to the crosslinking agent at $333 \mathrm{~K}$ to improve the rate of dissolution. The solution is then mixed with the epoxy resin to initiate crosslinking. The system is poured into a mould for testing mechanical properties of the blend. Once the blend hardens, it is heated for $3 \mathrm{~h}$ at $373 \mathrm{~K}$ to ensure complete crosslinking.

\subsection{Evaluation of Blends Properties}

Tensile and compressive properties were evaluated in accordance with ASTM D1708 and D786 standards, respectively. In addition, the T-peel strength and shear strength were determined by following ASTM D1876 and D1002 standards, respectively. All four of the previous tests were performed using a testing apparatus by Adamel Lhomargy Cia., type E630, model DY 22, with a capacity of $500 \mathrm{daN}$. The conditions were $296 \pm 2 \mathrm{~K}, 50 \pm 5 \% \mathrm{RH}$, and a crosshead speed of $5 \mathrm{~mm} / \mathrm{min}$. The flexural properties were evaluated in accordance with ASTM D790M standards, using an automated materials testing apparatus by Instron Corporation, Series IX, System 1.07. The impact strength specimens were prepared according to ASTM D256 procedure and were evaluated using a Charpy type impact testing machine from Shimatzu.

The melting and glass transition temperature of the blends was determined by using a DuPont DSC 2100 apparatus from the ambient temperature up to $573 \mathrm{~K}$. The conditions used were: heating rate $10 \% \mathrm{~min}$ and $\mathrm{N}_{2}$ atmosphere. Samples of the tensile fractured surfaces of the epoxy/NYLO66O blends were coated with a thin layer of colloidal silver and were observed in a JEOL 5200 SEM machine, at $25 \mathrm{kV}$ in a secondary electron mode.

\section{Results and Discussion}

Table 1 summarises the mechanical properties of the epoxy resin/NYLO66O blends of different compositions. The tensile strength and flexural modulus are seen to increase with the addition of NYLO66O up to a maximum at $2 \mathrm{wt} \%$ oligomer, an increase of $22 \%$ and $118 \%$ respectively, over that of the neat epoxy (Fig. 1). The tensile strain and impact strength (Fig. 3) both show a maximum due to the addition of $35 \mathrm{wt} \%$ NYLO66O. At a composition of $35 \mathrm{wt} \%$ oligomer there is $175 \%$ increase in the strain and $25 \%$ increase in the impact strength compared with the pure epoxy. A previous article in which NYLO66O was added to an unsaturated polyester resin showed a similar increase in both elongations to break and impact strength [6]. However, this article reported a maximum in impact resilience at a much smaller concentration of oligomer, approximately $2 \mathrm{wt} \%$. A peculiarity in the impact strength data is that there is an initial and drastic decrease in the impact strength with the addition of NYLO66O up to $10 \mathrm{wt} \%$. Previous papers on blends of polyurethane $[19,20]$ and polyethylene terephthalate oligomer [5] with a polyester resin have reported a sharp initial increase in the impact strength when the modifier was added, which levels off and then drops with increasing concentrations. The compressive strength testing revealed an increase of $87 \%$ over that of neat epoxy with the addition of $1 \mathrm{wt} \%$ NYLO66O (Fig. 2).

It is clearly seen that the modification of epoxy resin with NYLO66O increases all of the tested mechanical properties to some extent for the appropriate oligomer concentrations. The data reveal that up to approximately $2 \mathrm{wt} \%$ of oligomer the tensile, compressive, and flexural strength of the blend is increased. It would suggest that $2 \mathrm{wt} \%$ is the miscibility limit of this system. Up to this concentration the two constituents have a strong compatibility which leads to an increase in the strength of the epoxy. For concentrations $5 \mathrm{wt} \%$ and up the two phases appear to separate. The second phase, NYLO66O, seems to act as a plasticizer; increasing the flexibility, and thus the strain before failure, and as an impact modifier, absorbing the energy which the brittle epoxy matrix is unable to. It seems that the smaller molecular weight nylon 6,6 oligomer coats the stiff epoxy matrix and acts as a lubricant [9], allowing the chains to slide over each other, thus leading to an increase in flexibility. Blends with a concentration higher than $2 \%$ exhibit the typical tensile and impact strength decrease behaviour of previously reported interpenetrating networks with two phase morphology $[10,11]$. Normally, phase toughening of highly crosslinked thermoset resins, such as epoxy is difficult. The well established technology of rubber toughening is effective only for difunctional resins such as the diglycidyl ether of bisphenol A [11, 12]. This is because the highly crosslinked matrix has less capacity to deform by shear yielding. Therefore, successful toughening of these resins is achieved by introducing energy absorption processes that do not depend on the matrix ductility. Another possible explanation for the observed increase in blend strength is that epoxy is known to cure due to the presence of polymers containing amide groups. The NYLO66O used in our investigation contains a large percentage of these functional groups. In addition, it is possible that the oligomer has been polymerised to some extent by the crosslinking reaction of the epoxy resin. 
Mechanical behavior of the blends

Table 1

\begin{tabular}{|c|c|c|c|c|c|}
\hline \multirow{2}{*}{$\begin{array}{c}\text { NYLO660, } \\
\text { wt } \%\end{array}$} & $\begin{array}{c}\text { Tensile strength, } \\
\text { MPa }\end{array}$ & \multicolumn{2}{|c|}{ Tensile strain } & \multirow{2}{*}{$\begin{array}{c}\text { Compressive } \\
\text { strength, MPa }\end{array}$} & $\begin{array}{c}\text { Flexural modulus, } \\
\mathrm{J} / \mathrm{m}\end{array}$ \\
\cline { 3 - 6 } & 39.7 & 7.3 & $\mathrm{MPa}$ & 1032 & 13.61 \\
\hline 0 & 46.6 & 6.5 & $64.6(87 \%)^{*}$ & 2029 & 10.67 \\
\hline 1 & $48.4(22 \%)^{*}$ & 7.1 & 58.2 & $2250(118 \%)^{*}$ & 6.21 \\
\hline 2 & 42.7 & 7.6 & 52.5 & 1435 & 3.73 \\
\hline 5 & 35.7 & 13.9 & 33.8 & 377 & 6.42 \\
\hline 10 & 15.5 & $20.1(175 \%)^{*}$ & 22.9 & 72 & $16.32(20 \%)^{*}$ \\
\hline 35 & & & & & \\
\hline
\end{tabular}

* brackets indicate the maximum percentage increase compared with the neat epoxy

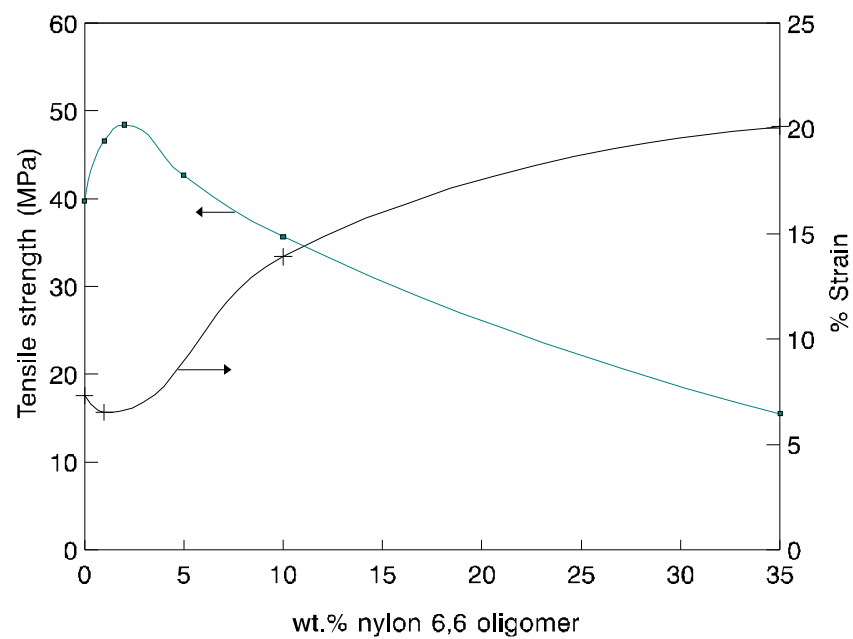

Fig. 1. Effect of NYLO66O concentration on tensile strength and strain

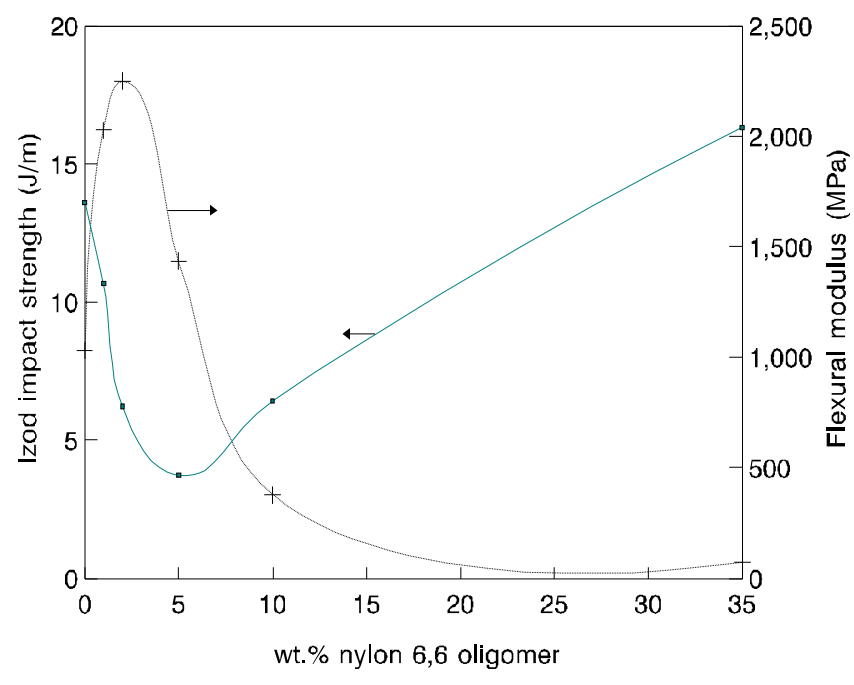

Fig. 3. Effect of NYLO66O concentration on impact strength and flexural modulus

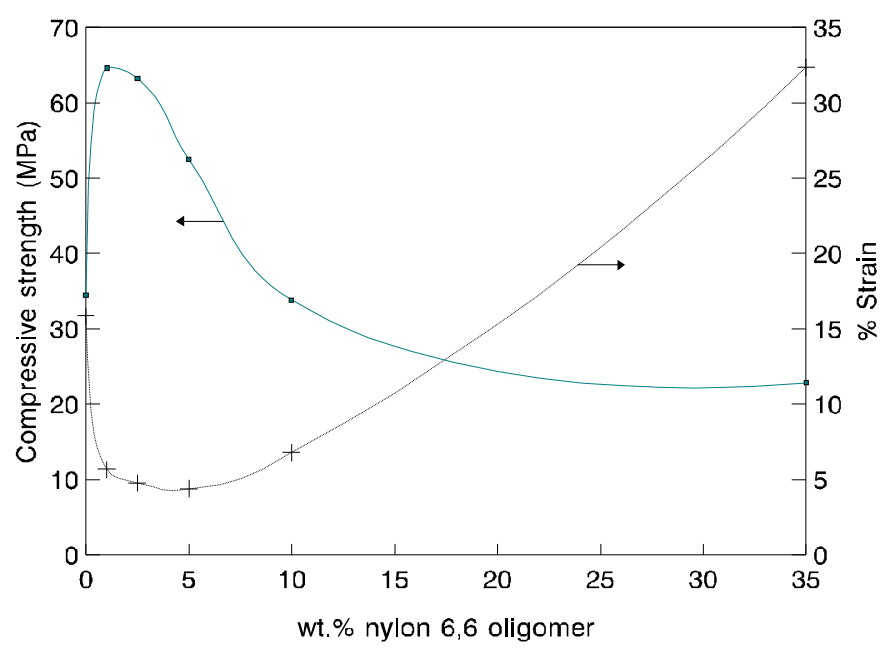

Fig. 2. Effect of NYLO66O concentration on compressive strength and strain

\subsection{Phase Separation: Morphology and Thermal Analysis}

The elaboration of a polymer alloy typically involves three successive steps: i) the choice of the constituent materials in relation to the expected properties of the blend; ii) control and characterisation of the blend morphology and iii) control of the interface between the constituents. When curing, epoxy undergoes complicated transformations in a physical state, from a viscous liquid to a gel, and eventually to a vitrified material. The morphology of a polymer blend typically depends on two factors: weight fraction of the constituents and their relative viscosities [13]. During blend preparation the epoxy is much more viscous than NYLO66O. Curing the epoxy increases a molecular weight and forms a rigid matrix while the oligomer takes on the consistency of a wax.

In this investigation the morphology and thus the blend properties were controlled by altering the composition alone. The results of the blends phase separation behaviour are summarised in Table 2 . 
Table 2

Morphological and thermal characteristics of the blends

\begin{tabular}{|c|c|c|c|c|}
\hline $\begin{array}{l}\text { NYLO660, } \\
\text { wt \% }\end{array}$ & $\begin{array}{c}T g \\
\mathrm{~K}\end{array}$ & $T_{M}, \mathrm{~K}$ & SEM & $\mathrm{DSC}^{*}$ \\
\hline 0 & 340 & & \multirow[t]{3}{*}{ no phase separation, homogeneous surface } & \multirow{3}{*}{$\begin{array}{c}\text { no phase separation, } 1 T g \text { peak } \\
\text { observed in thermogram }\end{array}$} \\
\hline 1 & 333 & & & \\
\hline 2 & 323 & & & \\
\hline 5 & 338 & & $\begin{array}{l}\text { phase separation, scattered clusters of } \\
\text { irregularly shaped particles }\end{array}$ & $\begin{array}{c}\text { phase separation, } 2 T g \text { peaks } \\
\text { observed in thermogram }\end{array}$ \\
\hline 10 & $\begin{array}{l}336 \\
315\end{array}$ & & \multirow{2}{*}{$\begin{array}{l}\text { phase separation, random clusters of } \\
\text { irregularly shaped particles + elongated } \\
\text { fibres protruding from surface flaws }\end{array}$} & \multirow[t]{2}{*}{$\begin{array}{c}\text { phase separation, } 2 T g \text { peaks } \\
\text { observed in thermogram }\end{array}$} \\
\hline 35 & $\begin{array}{l}333 \\
318\end{array}$ & & & \\
\hline 100 & 331 & 539 & homogeneous & $1 T g$ peak \\
\hline
\end{tabular}

* number of $T g$ present corresponds to the number of phases present

SEM micrographs show that the resulting material is completely homogeneous. The morphology of the epoxy/ NYLO66O blends remains unchanged for both 1 and 2 wt \% specimens. This highly homogeneous morphology is in agreement with previous work with blends of NYLO66O [6] and polycarbonate (PC). The research presented on the PC/epoxy resin concluded that the epoxy network formation follows a special mode [13]. The authors hypothesised that the reaction of the epoxide and amine groups may occur along the polycarbonate chains, so that the PC has a promotion effect on the curing reaction. This is not consistent with conventional mechanisms and is in sharp contrast to the highly inhomogeneous morphology observed even at low modifier concentrations with thermoset/thermoplastic blends of polyetherimide [1-3], polyethylene terephthalate oligomer [12], poly(butylene terephthalate) [1] and polysulfone [1-4]. Therefore, there exists a question concerning our system related to whether or not the oligomer has polymerised or crosslinked due to the epoxy. To answer this question DSC experiments are being conducted in our group to determine if the NYLO66O and epoxy retain their original thermal behaviour or if there exists an actual change.

The phase separation begins above 2 wt $\%$ NYLO66O. The phase separation continues for blends of 10 and 35 wt \% nylon 6,6 oligomer, however there are two distinct changes in the morphology of the second phase. The presence of fibre-like features raises an interesting question. Has the crosslinking reaction caused the NYLO66O oligomer to polymerise and/or crystallise? To answer this question TEM experiments were carried out to determine the nature and crystallinity of the fibres. TEM revealed, as expected, that the fibres are indeed semicrystalline nylon 6,6 polymer.

Miscible binary blends most often result from specific, favourable, exothermic interactions between two constituents. The crosslinking reaction of epoxy is known to be exothermic, however this cannot account for it alone because in other similar blends with epoxy and another polymer there was a considerable phase separation. The main features of the DSC analysis of various blend compositions are summarised in Table 2. The twofold decrease in the dynamic storage modulus (DMA) or in the heat evolved versus temperature curves indicating the phase separation via reaction induced (increase in a molecular weight) a spinodal decomposition.

The low-temperature $\tan \delta$ (endotherm) can be assigned to $T g$ of NYLO66O rich phase. The two higher endotherms are associated with the presence of some epoxy oligomer and the crosslinked epoxy network respectively. The presence of a small amount of epoxy oligomer in the neat epoxy system is most likely due to the microgel formation and chain scission of the epoxy network via established etherification.

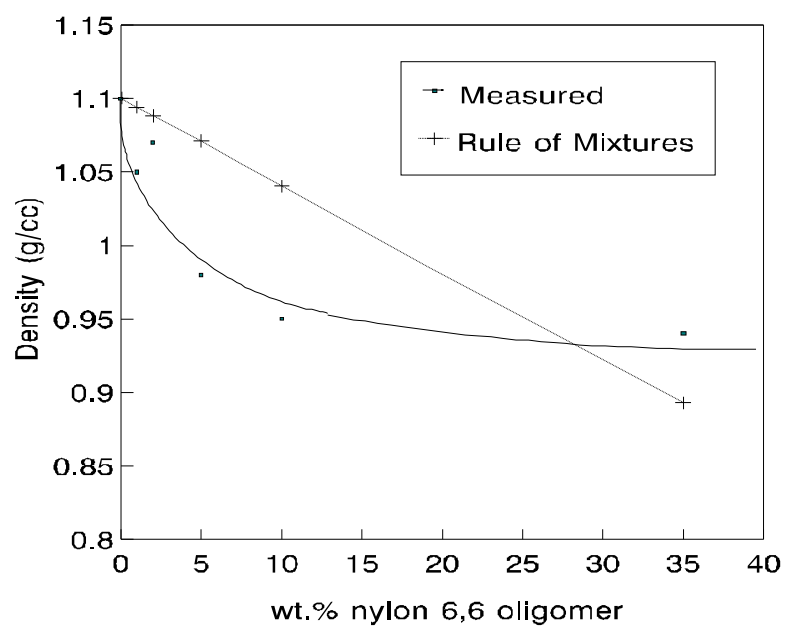

Fig. 4. Effect of NYLO66O concentration on blend density 
It is also interesting to observe how the density of the blends depends on the oligomer content (Fig. 4). As observed there, the measured density of the blends does not follow the standard rule of mixtures, which is drawn in the figures as a reference, indicating that there exists a reaction between the two components.

\section{Conclusions}

Novel epoxy/nylon 6,6 oligomer blends have been produced with varying concentrations of oligomer extracted from the industrial waste residues of nylon 6,6 manufacturing. The results show, first, the possibility of producing blends with controlled segregation behaviour through the manipulation of oligomer concentration and second, the relatively high degree of miscibility of the constituents which leads to a substantial increase in tensile, compressive, flexural and adhesive strength.

\section{Acknowledgements}

The authors are indebted to Mrs. J. Canetas and Mrs. A. del Real for the SEM characterisation, to Dr. A. Mondragon for her support in the FTIR experiments, and to Dr. A. Maciel for the use of the flexural and impact testing apparatus. One of the authors (J. P. Bragg) would like to acknowledge the support of The Theme School on New Materials and Their Impact on Society, McMaster University, Canada.

\section{References}

[1] Bucknall C. and Partridge I.: Polymer, 1983, 24, 639.

[2] Alvarez-Castillo A. and Castano V.: Polym. Bull., 1994, 32, 447.

[3] Alvarez-Castillo A. and Castano V.: $6^{\text {th }}$ Int. Macromol. Colloq., Gramado, Brasil, 1994, 1, 90.
[4] Huang M., Zhu K., Pearce E. and Kwei T.: J. Appl. Polym. Sci., 1993, 48, 563.

[5] Gandini A.: [in:] Allen G. (ed.), Comprehensive polymer science; polymers from renewable resources. Pergamon Press, New York 1992, 528.

[6] Rivera M., Robles-Vazquez J., Garcia-Garduno M. and Castano V.: Mat. Lett., 1993, 17, 84.

[7] Ika P., Frisch H. and Frisch K.: [in:] Klemdner D. (ed.), Advances in interpenetrating networks. Tehnomic Publ., Lancaster Brazil 1989, 11.

[8] Kim B. and Inoue T.: Polymer, 1995, 36, 1985.

[9] Ashby M. and Jones D.: Engineering materials 2: an introduction to microstructure, processing and design. Pergamon Press, New York 1992.

[10] Yee A. and Pearson R.: Tough composition materials research review. Noyes Pub., New Jersey 1987.

[11] Alvarez-Castillo A. and Castano V.: J. Mat. Sci. Lett., 1995, 14, 139.

[12] Lee L.: J. Appl. Polym. Sci., 1965, 9, 1981.

[13] Inoue H. and Matsukawa K.: J. Appl. Polm. Sci., 1992, 46, 363.

\section{СИНТЕЗ І ВЛАСТИВОСТІ СУМНШЕЙ ЕПОКСИДНА СМОЛА/ОЛІГОМЕР НАЙЛОН 6,6}

Анотація. Вивчено низку полімерних сумішей на основі різних складів епоксидна смола/олігомери Найлон 6,6. Отримані екстракиією з відпадів промислового виробниџтва Найлону 6,6 олігомери розчиняли в епоксидній смолі і зшивали при $333 \mathrm{~K} 3$ використанням додеценілянтарного ангідриду. Знайдено, щзо міџність до розривання та модуль згинання зростають із додаванням до 2 \% мас. Найлону. Введення у суміш $35 \%$ мас. Найлону підвищує мічність до розривання та ударну в'язкість. Наведені порівняльнітести для чистої епоксидної смоли і сумішей з додаванням Найлону. Встановлено залежність між механічними властивостями та морфологією сумішей.

Ключові слова: епоксидна смола, олігомери, сплав, механічні властивості, Найлон 6,6. 